\title{
Monocytes Chr9:112855726-113055726
}

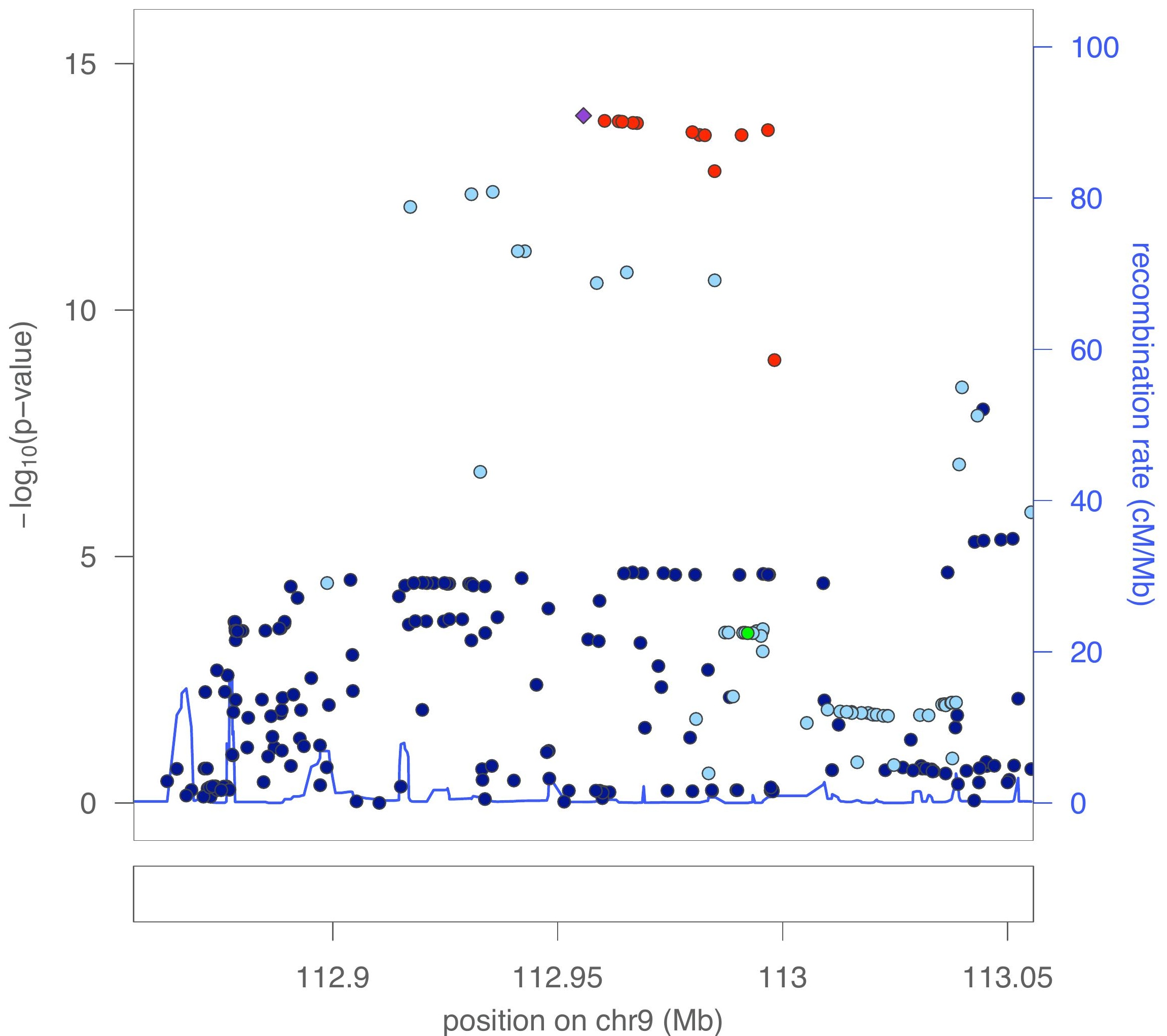

